Chirurgia (2019) 114: 200-206

No. 2, March - April

Copyright@ Celsius

http://dx.doi.org/10.21614/chirurgia.114.2.200

\title{
Emergency Surgery and Oncologic Resection for Complicated Colon Cancer: What Can We Expect? A Medium Volume Experience in Romania
}

\author{
Octavian Enciu, Valentin Calu, Mihai Angelescu, Mihai Alexandru Nădrăgea, Adrian Miron
}

Surgery Department, Elias University Emergency Hospital, Bucharest, Romania

"Carol Davila" University of Medicine and Pharmacy, Bucharest, Romania

Corresponding author:

Valentin Calu, MD

Surgery Department

Elias University Emergency Hospital

17, Marasti Blvd., District 1,

Bucharest, Romania

E-mail: drcalu@yahoo.com

Received: 10.03 .2019

Accepted: 13.04 .2019

\section{Rezumat \\ Chirurgie în urgență și rezecție oncologică pentru cancer de colon complicat: ce putem aștepta? Experiența unui Centru de Volum Mediu în România}

Introducere: Cancerul complicat de colon se prezintă cel mai adesea ca ocluzie intestinală şi necesită intervenție chirurgicală în urgență. Majoritatea pacienților primesc diagnosticul când se prezintă pentru o complicație a bolii, moment în care boala este de obicei avansată. În timp ce supraviețuirea pacientului primează, intenția curativă a rezecției conform principiilor chirurgiei oncologice poate cădea pe plan secund.

Material şi metodă: Am analizat retrospectiv 68 de pacienți consecutivi cu cancer de colon complicat care au suferit intervenții chirurgicale în urgență în perioada Ianuarie 2017 Septembrie 2018. Principiile rezecției oncologice au fost studiate în termeni de margini de rezecție şi număr de limfonoduli rezecați, şi/sau rezecții multiviscerale pentru a obține margini negative. Cincizeci şi opt de pacienți $(85.3 \%)$ au fost diagnosticați cu ocluzie intestinală, perforație intestinală a fost observată în 8 cazuri (11.8\%) în timp ce hemoragia digestivă inferioară a complicat 2 cazuri (2.9\%). Douăzeci şi doi pacienți au fost diagnosticați cu metastaze la distanță iar per total 29 pacienți $(42,6 \%)$ au fost încadrați în stadiul IV de boală. Margini circumferențiale de rezecție negative au fost obținute în $91 \%$ din cazuri în timp ce margini longitudinale invadate au fost observate în 2 cazuri iar numărul mediu de limfonoduli rezecați a fost mai 
mare de 13,7. Durata medie de spitalizare a fost de 13.9 zile iar mortalitatea postoperatorie observată a fost de $19.1 \%$.

Rezultate: Rezultatele chirurgicale pentru cancer de colon complicat în departamentul nostru se încadrează în datele publicate în literatură.

Concluzii: Principiile rezecției oncologice în ceea ce priveşte marginile de rezecție şi numărul de limfonoduli rezecați pot fi respectate în contextul intervenției chirurgicale în urgență şi oferă şansa de vindecare acestor pacienți cu boală avansată.

Cuvinte cheie: cancer de colon complicat, rezecție oncologică, chirurgie de urgență

\section{Abstract}

Introduction: Complicated colon cancer most frequently presents as obstruction and needs emergency surgery. Most of these patients receive their diagnosis when presenting for complicated disease and by that time the disease is usually advanced. While concerned first with the survival of the patient, the curative intent of the resection following the principles of oncologic resection may come in second place.

Materials and methods: We retrospectively analyzed 68 consecutive patients with complicated colon cancer that suffered emergency surgery between January 2017 and September 2018. The principles of oncologic resection were analyzed in terms of resection margins and retrieved lymph nodes and/or multivisceral resections in order to achieve clear margins. Intestinal obstruction was observed in 58 patients $(85.3 \%)$, perforation was found in 8 patients (11.8\%) while lower gastrointestinal bleeding complicated 2 cases $(2.9 \%)$. Twenty-two patients had distant metastases at presentation, and overall 29 patients $(42,6 \%)$ had stage IV disease. Clear circumferential margins were achieved in 55 cases while longitudinal margins were found to be invaded in 2 cases and the mean number of retrieved lymph nodes was greater than 13.7. The mean hospital stay was 13.9 days and the observed in hospital mortality was $19.1 \%$.

Results: The outcomes of surgery for complicated colon cancer in our department fall within the reported literature results.

Conclusion: The principles of oncologic resection in terms of surgical margins and retrieved lymph nodescan be respected during emergency surgery and offer the intent of cure for these patients with advanced disease.

Key words: complicated colon cancer, oncologic resection, emergency surgery

\section{Introduction}

Colorectal cancer accounted for $11.7 \%$ of all deaths from cancer in the EU in 2015 (1). The death rate was $75 \%$ higher in men than in women while the standardized death rate for persons aged 65 and over was many times higher than for younger persons (1). In Europe, only Germany and Austria have an efficient screening program with more than four fifths of their population aged 50 to 74 being screened while Romania and Bulgaria fall below 10\% of screened population.

Even in the context of efficient population screening and early diagnosis, emergency surgery for complicated colon cancer is required in up to $30 \%$ of patients $(2,3)$. It is expected that patients admitted in an emergency setting have more advanced disease. It is also reasonable to envisage that the current standards of oncologic resection are respected in a smaller scale in an emergency intervention where survival is 
the primary goal and a shorter operative time is demanded.

In the setting of emergency surgery for complicated colon cancer, mortality and morbidity increase manifold in comparison to elective surgery. The reported postoperative mortality is between $11.9 \%$ and $20 \%$ while morbidity rises to $64 \%$ (4-7). The reasons for this dismal situation are related to obstruction and its metabolic consequences, intestinal necrosis, perforation with peritonitis and systemic sepsis, not to add the comorbidities and usually the advanced age of the patients.

The aim of the study was to asses if the principles of oncologic resection were respected in terms of surgical margins and retrieved lymph nodes. This audit concerned consecutive cases irrespective of the surgeon that operated and surgical demeanor was thusly not influenced by the study.

\section{Methods}

Between January 2017 and September 2018, 227 patients underwent surgery for colorectal cancer in our unit: 141 elective interventions and 86 emergency interventions. Of the 86 patients with complicated colorectal cancer, 68 consecutive patients were diagnosed with colon cancer and underwent surgery within 24 hours. Complete diagnosis was achieved by
CT scan, and the disease was staged according to TNM staging of AJCC 8th edition (8). Retrieved data included demographic characteristics, comorbidities, ASA score, mean hospital stay and mean CR-POSSUM as a tool for quality of care (Table 1). Tumor location, staging, types of surgical intervention and timing of surgery are listed in Table 2. Postoperative complications are recorded in Table 3. The audit of resection in terms of surgical margins and retrieved lymph nodes is listed in Table 4. The study was approved by the Ethics Committee of Elias Emergency University Hospital.

\section{Results}

All 68 patients were admitted through our Emergency room and the diagnostic algorithm included CT scan for all patients. Staging was achieved after initial abdominal CT scan when tumors were diagnosed, the lung was scanned in the same setting.

The timing of surgery was considered urgent for patients with important abdominal distension, respiratory distress and for the patients with signs of sepsis. Nineteen patients underwent emergency surgery, typically within 6 hours after admission and 49 patients suffered surgery within 24 hours, time used to optimize the patient's physiology.

Table 1. Demographic characteristics, comorbidities and risk factors

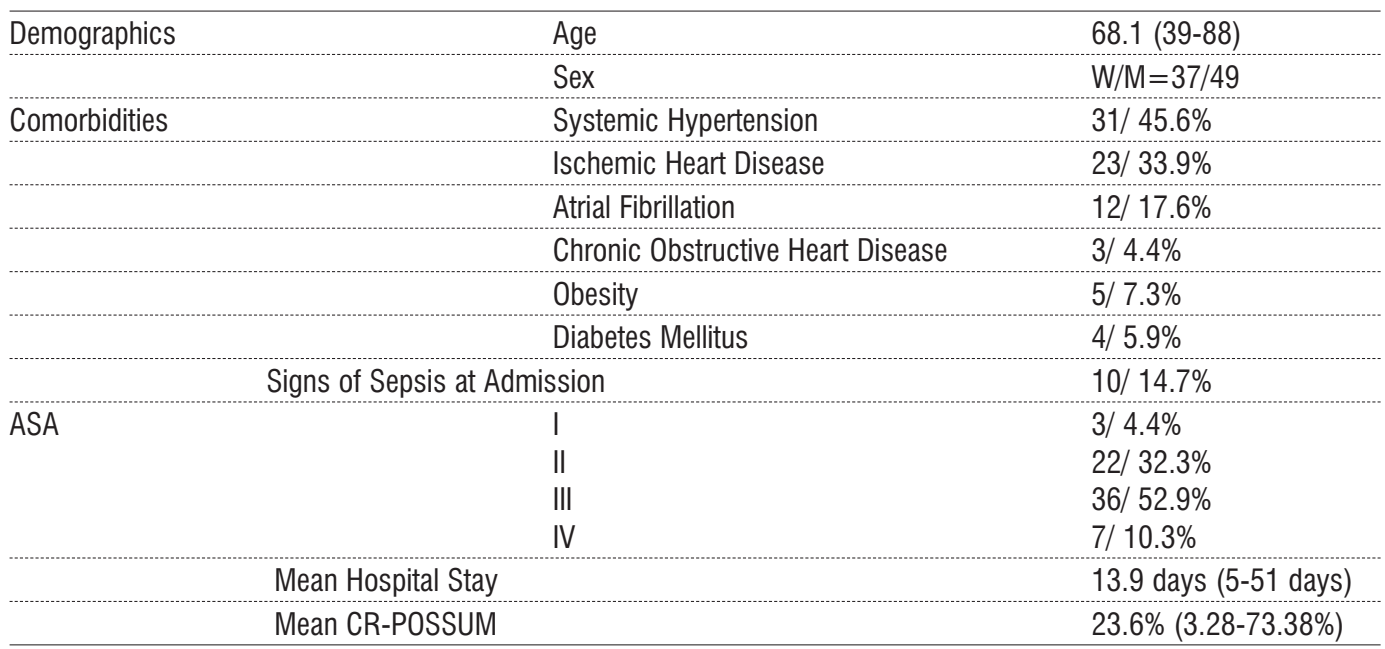


Table 2. Tumor location, Complications, Staging, Metastases, Timing of Surgery, Types of intervention and additional resections

\begin{tabular}{|c|c|c|c|}
\hline \multirow[t]{5}{*}{ Tumor location } & Right colon & $\begin{array}{l}\text { Cecum } \\
\text { Ascending colon }\end{array}$ & $\begin{array}{l}4 / 5.9 \% \\
6 / 8.8 \%\end{array}$ \\
\hline & Transverse colon & & $11 / 16.2 \%$ \\
\hline & Left colon & $\begin{array}{l}\text { Splenic Flexure } \\
\text { Descending colon }\end{array}$ & $\begin{array}{c}9 / 13.2 \% \\
14 / 20.6 \%\end{array}$ \\
\hline & Sigmoid colon & & $17 / 25 \%$ \\
\hline & Rectosigmoid junction & & $7 / 10.3 \%$ \\
\hline \multirow[t]{3}{*}{ Complication } & Obstruction & & $58 / 85.3 \%$ \\
\hline & Perforation & $\begin{array}{l}\text { Diastatic perforation } \\
\text { Tumoral perforation }\end{array}$ & $\begin{array}{l}7 / 10.3 \% \\
1 / 1.5 \%\end{array}$ \\
\hline & Hemorrhage & & $2 / 2.9 \%$ \\
\hline \multirow[t]{7}{*}{ Staging } & $\|A-\| B$ & & $3 / 4.4 \%$ \\
\hline & IIC & & $7 / 10.3 \%$ \\
\hline & IIIA & & $5 / 7.3 \%$ \\
\hline & IIIB & & $11 / 16.2 \%$ \\
\hline & IIIC & & $13 / 19.1 \%$ \\
\hline & IVA - IVB & & $21 / 30.9 \%$ \\
\hline & IVC & & $8 / 11.8 \%$ \\
\hline \multirow[t]{4}{*}{ Distant metastases } & Liver & & $11 / 16.2 \%$ \\
\hline & Lung & & $7 / 10.3 \%$ \\
\hline & Lung and liver & & $4 / 5.88 \%$ \\
\hline & Peritoneal metastasis & & $8 / 11.8 \%$ \\
\hline \multirow[t]{2}{*}{ Timing of surgery } & Emergency & & $19 / 27.9 \%$ \\
\hline & Within 24 hours & & $49 / 72.1 \%$ \\
\hline \multirow[t]{10}{*}{ Intervention } & Stoma formation & $\begin{array}{l}\text { Colostomy } \\
\text { Lateral ileostomy }\end{array}$ & $\begin{array}{l}4 / 5.9 \% \\
2 / 2.9 \%\end{array}$ \\
\hline & Hartmann's resection & & $24 / 35.3 \%$ \\
\hline & Right colectomy with anastomosis & & $10 / 14.7 \%$ \\
\hline & Right extended colectomy with anastomosis & & $11 / 16.2 \%$ \\
\hline & Left colectomy with anastomosis & & $5 / 7.3 \%$ \\
\hline & Sigmoid resection with anastomosis & & $3 / 4.4 \%$ \\
\hline & Rectosigmoid resection with anastomosis & & $4 / 5.9 \%$ \\
\hline & & Diverting ileostomy & 3 \\
\hline & Subtotal colectomy with anastomosis & & $3 / 4.4 \%$ \\
\hline & Subtotal colectomy with end ileostomy & & $2 / 2.9 \%$ \\
\hline \multirow[t]{6}{*}{ Multivisceral resections } & Enterectomy & & $5 / 7.4 \%$ \\
\hline & Partial gastrectomy - wedge resection & & $2 / 2.9 \%$ \\
\hline & Parietal resection & & $6 / 8.8 \%$ \\
\hline & Hysterectomy with/without adnexectomy & & $3 / 4.4 \%$ \\
\hline & Adnexectomy & & $2 / 2.9 \%$ \\
\hline & Partial urinary bladder resection & & 2/ $2.9 \%$ \\
\hline
\end{tabular}

Obstruction complicated 58 cases of colon cancer $(85.3 \%)$ while perforation was the complication that led to the diagnosis in 8 cases $(11.8 \%)$. Hemorrhage concomitant with recurrent symptoms of obstruction complicated one case of sigmoid cancer. Most of tumors in the studied group were located on the left colon. Twenty-two patients had distant metastases while 8 had also significant peritoneal metastases. For patients with massive peritoneal metastases tumor resection was abandoned and stoma formation was considered the safe option for relieving the obstruction.

Primary anastomosis was performed in all right sided lesions while on the left side Hartmann's resection dominated the interven- 
Table 3. Postoperative complications

\begin{tabular}{|c|c|c|c|}
\hline Complication & & & No/\% \\
\hline Anastomotic dehiscence (36 anastomoses) & $\begin{array}{l}\text { Right side resections } \\
\text { Left side resections } \\
\text { Subtotal colectomy }\end{array}$ & $\begin{array}{l}3 / 8.3 \% \\
4 / 11.1 \% \\
1 / 2.8 \%\end{array}$ & $8 / 22.2 \%$ \\
\hline Stoma complications (35 colostomies and ileostomies) & $\begin{array}{l}\text { Colostomy } \\
\text { lleostomy }\end{array}$ & & $\begin{array}{l}5 / 14.2 \% \\
3 / 8.6 \%\end{array}$ \\
\hline Evisceration & & & $4 / 5.9 \%$ \\
\hline Wound sepsis & & & $7 / 10.3 \%$ \\
\hline Pneumonia & & & $8 / 11.8 \%$ \\
\hline Cardiac complications & & & $5 / 7.3 \%$ \\
\hline Septic shock & & & $3 / 4.4 \%$ \\
\hline
\end{tabular}

tions performed for left sided tumors. Overall, resection with primary anastomosis was performed in 36 cases $(52.9 \%)$ while resection with stoma formation was performed in 26 cases (38.3\%). Anastomosis dehiscence was observed in 8 cases $(22.2 \%)$.

In order to keep resections margins free, additional resections were performed in young patients with good clinical and biological status. Even if in the setting of emergency surgery this is not considered orthodox practice, these resections did not significantly prolong operative time and did not led to significant morbidity.

Overall morbidity was $37 \%$, with significant occurrence of systemic complications, and perioperative (defined as 30 days after surgery) mortality for the studied group was $19.1 \%$. The mean hospital stay was 13.9 days (range 5-51 days).

With 62 tumoral resections performed out of 68 cases of complicated colon cancer, negative circumferential margins were obtained in 55 cases. In six cases with large T4 tumors and one case with tumoral perforation, circumferential margins returned positive. On final pathology, 2 cases had positive longitudinal margins.

In terms of retrieved lymph nodes, in the studied group, the mean number of retrieved lymph nodes was greater than 13.7. In our study, the lowest number (under 12) of retrieved lymph nodes was found after resections for sigmoid and descending colon tumors. The pathology examinations followed

Table 4. Surgical Margins and Lymph nodes retrieved

\begin{tabular}{|c|c|c|c|c|}
\hline \multirow[t]{7}{*}{ Lymph nodes } & \multicolumn{2}{|l|}{ Lymph nodes retrieved by tumor location } & \multirow{2}{*}{$\begin{array}{l}\text { Mean } \\
16.1\end{array}$} & \multirow{2}{*}{$\begin{array}{c}\text { Range } \\
(12-27)\end{array}$} \\
\hline & Right colon & & & \\
\hline & Transverse colon & & 15.5 & $(14-27)$ \\
\hline & Left colon & Splenic flexure & 15.2 & $(13-19)$ \\
\hline & & Descending colon & 16.7 & $(11-20)$ \\
\hline & Sigmoid colon & & 13.7 & $(7-20)$ \\
\hline & Rectosigmoid junction & & 16.12 & $(15-25)$ \\
\hline Surgical Margins & \multicolumn{4}{|l|}{ Positive surgical margins by tumor location } \\
\hline \multirow[t]{4}{*}{ Circumferential } & Right colon & & 3 cases & \\
\hline & Descending colon & & 2 cases & \\
\hline & Splenic flexure & & 1 case & \\
\hline & Sigmoid colon & & 1 case & \\
\hline \multirow[t]{2}{*}{ Longitudinal } & Transverse colon & & 1 case & \\
\hline & Descending colon & & 1 case & \\
\hline
\end{tabular}


standard protocols with no specific requests regarding this study.

\section{Discussion}

Obstruction is the most common complication of colon cancer and emergency surgery carries more morbidity and morbidity than elective surgery (9-11). Furthermore, emergency surgery is associated with worse prognosis and lower survival rates (12-14). Colonic stenting has emerged as a new option for bridging colonic obstruction into elective surgery but available shows oncological issues regarding local and systemic recurrence $(15,16)$.

While standards of oncologic resections are established for elective surgery, emergency surgery for complicated colon cancer is less standardized. These patients have advanced disease at presentation, large tumors and frequently distant metastases. Complete mesocolic excision may offer a superior resection specimen but it is difficult to imagine mesocolic excision in an emergency setting (17). Surgeons might be discouraged to employ radical surgery due to poor clinical status of the patient. Several other aspects are to be considered: the distended colon is difficult to mobilize, vascular dissection is cumbersome, the risk of contamination is very high and longer operative time further alters the physiology of the patient.

In the study group, 22 patients had distant metastases and overall 29 patients had stage IV disease. Apart for those with significant peritoneal metastases, local tumoral resection was satisfactory. Clear margins were obtained in most specimens. The mean number of retrieved lymph nodes was greater than 13.7. Smaller number of lymph nodes (in range) were reported for left sided tumors, sigmoid colon and descending colon. In 7 cases (10.3\%) the number of lymph nodes retrieved with the specimen was lower than the current oncologic standard (18).

Resection of additional tissue attached to the tumor to obtain clear circumferential margins was performed. In 14 cases (22.6 of all tumoral resections), additional resections were required. From parietal resections for tumors attached to the parietal peritoneum to gastrointestinal wedge resections with mechanical suture, these interventions did not significantly increase operative time.

In our group, 29 patients had stage IV disease. The audit we performed on pathology reports confirms that local tumoral resections was within current standards of colorectal surgery. This may not benefit the stage IV patients but it must offer a better chance for adjuvant therapy for all the rest.

The morbidity and mortality within the studied group falls within the reported literature data $(5,7)$. With the data available in the patient chart, CR-POSSUM was calculated for every case as a tool to measure the quality of care (19). Even published data suggests that CR-POSSUM over estimates mortality, the observed mortality (13 patients) in our study group was significantly less than the estimated mortality (19.1\% vas $23.6 \%$ ).

One can ask if this manner of surgical resection for complicated tumors of the colon is beneficial for patients with advanced disease. The current published data cannot answer this question. Interventions for complicated colon cancer are more frequently performed by general surgeons than colorectal surgeons. Current published data suggests that better survival is achieved by surgeons with a higher degree of specialization (20).

\section{Conclusion}

The principles of oncologic resection can be respected during emergency surgery for complicated colon cancer and may offer a significant chance for long-term survival for patients without stage IV disease. Mortality and morbidity are increased by the poor condition of the patients and by attributes of advanced neoplastic disease.

\section{Conflict of Interest}

The authors declare no conflicts of interests. 


\section{References}

1. Available from: https://ec.europa.eu/eurostat/statistics-explained/ index.php/Cancer_statistics_-_specific_cancers\#Colorectal_cancer.

2. Waldron R, Donovan I, Drumm J, Mottram S, Tedman S. Emergency presentation and mortality from colorectal cancer in the elderly. British journal of surgery. 1986;73(3):214-6.

3. Scott N, Jeacock J, Kingston R. Risk factors in patients presenting as an emergency with colorectal cancer. British journal of surgery. 1995;82(3):321-3.

4. Smothers L, Hynan L, Fleming J, Turnage R, Simmang C, Anthony T. Emergency surgery for colon carcinoma. Diseases of the colon \& rectum. 2003:46(1):24-30.

5. Ascanelli S, Navarra G, Tonini G, Feo C, Zerbinati A, Pozza E, et al. Early and late outcome after surgery for colorectal cancer elective versus emergency surgery. Tumori Journal. 2003;89(1):36-41.

6. Tekkis PP, Kinsman R, Thompson MR, Stamatakis JD, Britain AoCoG. The Association of Coloproctology of Great Britain and Ireland study of large bowel obstruction caused by colorectal cancer. Annals of surgery. 2004;240(1):76.

7. Teixeira F, Akaishi EH, Ushinohama AZ, Dutra TC, do Couto Netto $\mathrm{SD}$, Utiyama EM, et al. Can we respect the principles of oncologic resection in an emergency surgery to treat colon cancer? World Journal of Emergency Surgery. 2015;10(1):5.

8. Gospodarowicz MK, Brierley JD, Wittekind C. TNM classification of malignant tumours: John Wiley \& Sons; 2017.

9. Trétarre $B$, Marchigiano $E$, Millat $B$, Daurès J-P, Borie $F$. Management and prognosis of colon cancer in patients with intestinal obstruction or peritonitis: a French population-based study. Medical science monitor. 2005;11(6):CR266-CR73.

10. Biondo S, Kreisler E, Millan M, Fraccalvieri D, Golda T, Ragué JM, et al. Differences in patient postoperative and long-term outcomes between obstructive and perforated colonic cancer. The American Journal of Surgery. 2008;195(4):427-32.

11. Biondo S, Martí-Ragué J, Kreisler E, Parés D, Martín A, Navarro M, et al. A prospective study of outcomes of emergency and elective surgeries for complicated colonic cancer. The American journal of surgery. 2005;189(4):377-83.

12. McArdle C, Hole D. Emergency presentation of colorectal cancer is associated with poor 5-year survival. British journal of surgery. 2004;91(5):605-9.

13. Alvarez JA, Baldonedo RF, Bear IG, Truán N, Pire G, Alvarez P. Presentation, treatment, and multivariate analysis of risk factors for obstructive and perforative colorectal carcinoma. The American journal of surgery. 2005;190(3):376-82.

14. Degett TH, Dalton SO, Christensen J, Søgaard J, Iversen LH, Gögenur I. Mortality after emergency treatment of colorectal cancer and associated risk factors - a nationwide cohort study. Int J Colorectal Dis. 2019;34(1):85-95. Epub 2018 Oct 16.

15. Foo CC, Poon SHT, Chiu RHY, Lam WY, Cheung LC, Law WL. Is bridge to surgery stenting a safe alternative to emergency surgery in malignant colonic obstruction: a meta-analysis of randomized control trials. Surg Endosc. 2019;33(1):293-302. Epub 2018 0ct 19.

16. Cao Y, Deng S, Wu K, Zheng H, Cheng P, Zhang J, et al. Oncological consequence of emergent resection of perforated colon cancer with complete obstruction after stent insertion as a bridge to surgery. Int $J$ Colorectal Dis. 2019;34(3):545-547. Epub 2018 Aug 8.

17. Hohenberger W, Weber K, Matzel K, Papadopoulos T, Merkel S. Standardized surgery for colonic cancer: complete mesocolic excision and central ligation-technical notes and outcome. Colorectal disease. 2009;11(4):354-64.

18. Nelson H, Petrelli N, Carlin A, Couture J, Fleshman J, Guillem J, et al. Guidelines 2000 for colon and rectal cancer surgery. Journal of the National Cancer Institute. 2001;93(8):583-96.

19. Senagore AJ, Warmuth AJ, Delaney CP. Tekkis PP, Fazio VW. POSSUM, p-POSSUM, and Cr-POSSUM: implementation issues in a United States health care system for prediction of outcome for colon cancer resection. Diseases of the colon \& rectum. 2004; 47(9):1435-41.

20. McArdle C, Hole D. Influence of volume and specialization on survival following surgery for colorectal cancer. British Journal of Surgery. 2004;91(5):610-7. 